\title{
Discovery of meteoritic calzirtite in Leoville: A new ultrarefractory phase from the solar nebula
}

\author{
CHI MA
}

Division of Geological and Planetary Sciences, California Institute of Technology, Pasadena, CA 91125, USA

(chima@caltech.edu)

During a nanomineralogy investigation of the Leoville CV3 carbonaceous chondrite, calzirtite $\left(\mathrm{Ca}_{2} \mathrm{Zr}_{5} \mathrm{Ti}_{2} \mathrm{O}_{16}\right)$ was identified in an ultrarefractory inclusion within an amoeboid olivine aggregate, using field-emission scanning electron microscope (SEM), energy-dispersive X-ray spectroscopy (EDS) and electron back-scatter diffraction (EBSD) analyses. Reported here is the discovery of calzirtite in a primitive meteorite, as one of first formed solids in the solar system.

Calzirtite occurs as irregular grains $(0.5-1.5 \mu \mathrm{m}$ in size $)$, in zirconolite, along with hexaferrum and perivskite (Fig. 1), occupying the core area in an ultrarefractory inclusion with a rim consisting of $\mathrm{Zr}$,Sc-rich grossmanite, surrounded by olivine. The chemical composition of calzirtite by SEM-EDS is (wt\%) $\mathrm{ZrO}_{2} 68.8, \mathrm{TiO}_{2}$ 14.4, $\mathrm{CaO} 9.1, \mathrm{Y}_{2} \mathrm{O}_{3} 6.8, \mathrm{Sc}_{2} \mathrm{O}_{3}$ 1.0, giving rise to an empirical formula (based on $16 \mathrm{O}$ atoms $p f u$ ) of $\left(\mathrm{Ca}_{1.50} \mathrm{Y}_{0.50}\right) \mathrm{Zr}_{5.00}\left(\mathrm{Ti}^{4+}{ }_{1.32} \mathrm{Zr}_{0.17} \mathrm{Ti}^{3+}{ }_{0.34} \mathrm{Sc}_{0.12} \mathrm{Y}_{0.05}\right) \mathrm{O}_{16}$, with $\mathrm{Ti}^{4+}$ and $\mathrm{Ti}^{3+}$ partitioned on stoichiometry. EBSD analysis revealed that calzirtite has a tetragonal $I 4_{1} /$ acd structure, identical to that of synthetic $\mathrm{Ca}_{2} \mathrm{Zr}_{5} \mathrm{Ti}_{2} \mathrm{O}_{16}$, showing $a=15.21$ $\AA, c=10.11 \AA$ and $Z=8$.

Calzirtite joins other Zr-rich minerals from carbonaceous chondrites, including allendeite, tazheranite, lakargiite, zirconolite, kangite, panguite, baghdadite, zirkelite, and baddeleyite. Calzirtite probably formed by condensition or crystallized from a refractory melt in the solar nebula.

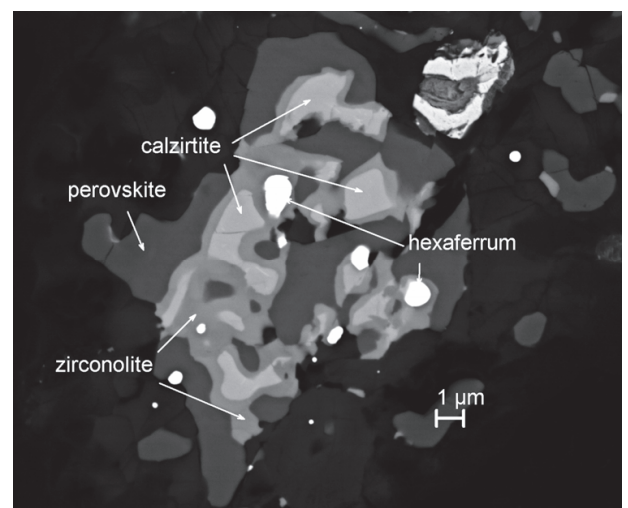

Figure 1: Back-scatter electron image showing calzirtite with zirconolite, hexaferrum and Y-rich perovskite in Leoville. 